\section{FISCAL STIMULATIONS FOR IMPROVING THE BUSINESS ENVIRONMENT IN REPUBLIC OF MACEDONIA}

\section{JEL Classifications: E6}

STEVAN GABER,

Department of Economics

University "Goce Delcev", Macedonia

Key words: Budget deficit financing, restrictive monetary policy, policy coordination, bank reserve rate requirement.

\begin{abstract}
In conditions when the national economy is hit hard with catastrophic economic consequences from financial crises, mutual coordinative approach between fiscal authorities and independent monetary institution, entrusted for macroeconomic stability, is particularly essential. This paper focuses on the situation, when there is not, at least temporary, constructive dialog between the two most important institutions in the country, and consequences are paid by enterprises and citizens.
\end{abstract}

In terms of enormous economic impacts from the world economic crises in most countries around the world, that were sensed everywhere, Macedonia is handling the consequences on satisfactory level. The implementation of the fiscal policy was realized according to the ambitious government program with certain later exclusions in coordination with financial institutions. However the first wave that started to announce the presence of the crises came the last quarter of 2008, caused by the reduced liquidity of the banking sector. In terms of endangered capital flows, the National Bank of the Republic of Macedonia (NBRM) offered the banks to keep all the foreign currency in its treasury under the same interest rates as those in the Euro zone.

Until the previous year Macedonia have had the biggest rate of economic growth since its independence $(5.9 \%$ in 2007 and 5\% in 2008), but suddenly the following year happened the opposite situation - contraction, which normally was expected. The initial indicator was certainly the current account deficit, impacted through decreased export prices and the reduced demand from the European Union, as major economic partner of Macedonia. In low exploitation of production capacities and intensively growing trade deficit, the foreign currency reserves of the NBRM were brought to question, because only in period of three months the NBRM intervened with substantial amount on the currency market with intention to defend the fixed exchange rate regime.

When the country makes the decision which sources (taxes or borrowing) to use in financing the expansive fiscal policy, usually the more suitable is public debt. In economy where the financial markets are depressed and the capital flow is limited, it is expected from the government to intervene and through their fiscal instruments - taxes and public expenditures - to increase the level of aggregate demand, production, employment and finally economic growth. Therefore, the government used the both reliable measures to boost the output. It reduced the personal income tax from 15, 18 and $24 \%$ to $12 \%$ in 2007 and $10 \%$ in 2008 , corporate tax from $15 \%$ on $10 \%$ and increased their public expenditures through a number of infrastructure projects. The Macedonian government in this sense was already engaged in pro-active fiscal policy regarding the significant unused economic potential and was able to reply in time to the expected economic difficulties. It had budget surplus of $0.6 \%$ of GDP in 2007 and $1 \%$ of GDP deficit in
2008. These major economic activities were based upon foreign direct investments and transfers from abroad. Through the regular activities, the government decided to secure additional capital through public debt increase for securing sources for there projects in this difficult time. As the situation on the world capital market was going worse and further international borrowing appeared unlikely, the government turned to the domestic capital market as potential source of capital. The available potential for further development of the capital market was a condition for the government to try and test the market to secure additional funds with issue of government securities.

The necessity to finance the deficit in line of expansive fiscal policy led to the increase in the interest rates for short term government securities. On the auction in April 2009, the government succeeded to secure 207 million Euro at $8.9 \%$ rate, opposite to NBRM securities (Central Bank bills) that provided secured 39.2 million Euro on $7.5 \%$ interest rate. This government necessity for financial capital caused increase of the basic interest rate, according to which the commercial banks create their credit analysis. On the next auction the interest rate of the Treasury Bills raised till $9 \%$. These short-term TCB bills and Treasury bills are securities of exceptional importance, because through them the NBRM provides signals and regulates the monetary conditions on domestic market. This inconvenient situation between the Ministry of finance and NBRM was the trigger to more restrictive monetary policy.

For economies like the Macedonian, which are not intensively involved on international capital market, coverage of import of goods and services with currency reserves is usually the main economic index. The index decreased from 4.1 in 2006 to 3.5 months of imports in 2008 according to NBRM data. In these circumstances for the NBRM, entrusted to secure macroeconomic stability, there was left only one thing to do - to increase the required reserves as the most effective monetary instrument in traditional banking system. Taking into consideration that the Macedonian economy runs regime of fixed exchange rate, the obligation to restrain the inflation rate, which until the whole last year was around $10 \%$, led to severe economic consequences for the business sector (reducing competitiveness, production and employment), and the households (reducing the consumption and increasing the savings) throwing the economy in recession. So, this tight communication between the government and the monetary 
authority led to increasing by NBRM the reserve requirement obligations ratio. The National Bank of Republic of Macedonia increased the rate from 10 to $13 \%$ for all the credits denominated in foreign currency. Therefore, implementing this direct monetary instrument provided necessary tightening of monetary policy in order to secure the exchange rate pressure. This way, the monetary authorities demonstrated their independence and responsibility in sustaining monetary stability in the economy. For their expedient response to the current market situation, they have received compliments form the recent mission of IMF.

However, the recent unpleasant events brought attention to the government that despite their considerations of free room for relaxed economic policy, it is better to cooperate and act through collective and coordinative policies. The most popular hope of corporate sector is the expected and guaranteed by the government credit line of 100 million Euro from European Investment Bank. Such credit is planned to be placed with the Macedonian Bank for Support of Development and other 7 other banks in the country. On receiving this credit, these banks are assumed to channel investment loans to the firms at $6 \%$ interest rate. In this scenario, projects in energy sector, industry, health, education and tourism will be given priority to finance. The plans of the Government and the banking sector are to gather 150-180 million Euro for financing small and medium firms. The other measure is revision of the budget, caused by decreased revenues, and normally adequate response on the expenditure size of the budget in order to detain the planed budget deficit rate. Thus, the final measure would be substantial investment in infrastructure projects for roads, railway, industrial infrastructure and other capital projects.

The above described case represents the essential conflict in interests between the monetary and fiscal policy. It is of crucial importance that in time of crises these policies should be carefully coordinated to cope with recession and provide optimal exit strategy from the financial crisis. That was partly managed with issue of Eurobonds. So the external sources make less pressure on the domestic money market. In the future there are also other opportunities for borrowing, and those will be reviewed upon the revised economic policy. However, it is important to state that the government takes all precautionary measures in order to secure positive rate of economic growth. The last IMF prognoses are growth decrease from $1-1.5 \%$ of GDP for this year, and growth rate of $2 \%$ for the 2010. This is additional approval from world important institution for the current state of economic policy in the country.

\section{References}

Atanasovski, Z., 2004. Public Finance, University "St. Cyril and Methodius", Economic faculty, Skopje.

Barro, R., 2000. Macroeconomics, The MIT Press, 3rd Edition.

Rosen, S., 2002. Public Finance, McGrow-Hill Irwin, 6th Edition.

Trpeski, L., 2003. Money and Banking, Economic Press, Skopje.
Spilimbergo, A., Symansky S., Blanchard O., and Cottarelli, C., 2008. "Fiscal Policy for the Crisis", IMF Staff Position Note, December 29, SPN/08/. 